\title{
COCONUT TAPPING IN THE PHILIPPINES ENIGMAS AND OBSERVATIONS
}

\author{
By \\ Rebecco M. Santiago and Ma Solita J. Virtudazo ${ }^{1}$
}

\begin{abstract}
Individual interviews were conducted to 24 purposively selected coconut tappers from Leyte, Samar and Cebu, Philippines to determine their tapping practices and observations and knowledge on certain phenomena exhibited by the tapped palm, as well as, the problems which confront them. Specifically, inquiries were focused on tree selection, spadix/inflorescence age appropriate for tapping, spadix preparation and stimulation, spadix care and maintenance, climatic considerations and relations, and temporary cessation of inflorescence production.

Data revealed certain enigmatic phenomena and some inconsistencies to long-held physiological facts. Moreover, respondents' observations strongly point out the toddy yield's extreme sensitivity to climatic and weather change which could be best validated by further coconut physiology research.
\end{abstract}

\section{INTRODUC'TION}

Sap flow from a tapped coconut inflorescence has up to the present remained enigmatic. The tapping process per se is simple, but it is the physiological nature of the coconut tree which eluded explanations from plant physiologists.

Toddy production is an important component of the coconut industry $m$ the Philippines, yet research work about it has been scanty. This probably explains why existing tapping technologies have ail been developed by the tappers themselves-virtually nothing has come from the scientific community.

Early literature point out that tapping has been an age-old activity among people of different nationalities and cultures. In India, for instance, coconut (Cocos Nucifera), palmyra palms (Borassus flabellifer), Indian sago palm (Caryota urens) and the wide date (Phoenix sylvestris) are the most common palms tapped (Mennon and Pandalai, 1958). However, expectedly, tapping practices vary with people and geographic origins. While tapping has been a long established folk technology in the Philippines, it is believed that much has to be done to elevate its status from a backyard livelihood activity to a highly profitable enterprise.

This paper presents the results of the mini-survey conducted among selected coconut tappers in three provinces in Central Philippines. Particularly, this report highlights respondents' knowledge and practices and the various enigmatic phenomena exhibited by the tapped palm which confront local tappers. This also seeks to obtain relevant information based on their experiences which may prove helpful in effecting improvements on the existing tapping technology.

\section{METHODOLOGY}

Purposive random sampling was employed in drawing 24 sample respondents from a population of coconut tappers in Leyte, Samar and Cebu provinces in Central Philippines. Tappers were selected based on their consistency in performing tapping operations and willingness to be interviewed personally.

\footnotetext{
${ }^{1}$ Researchers, Regional Coconut Research Center, VisCA, Baybay, Leyte 6521-A, Philippines.
} 
An interview schedule was constructed, and translated. into the respondents' dialect to serve as a data-gathering instrument of this mini-survey. Individual interviews were conducted to 24 tapper-respondents. To thoroughly capture individual responses, interview questions were mostly open-ended. The major points of inquiries included. in the interview were on (a) selection of trees for tapping, (b) age of spadix/inflorescence appropriate for tapping, (c) preparation and stimulation of the spadix for tapping, (d) care and maintenance of the spadix being tapped, (e) climatic considerations and relations, and (f) temporary cessation of inflorescence production.

\section{RESULTS AND DISCUSSION}

\section{Respondents' profile}

Half of die respondents were from the Leyte province, specifically from the Western, Northern and Southern Leyte areas, principally because of their proximity to the researchers (Table 1). The rest were from Cebu (2 9\%) and Eastern Samar (2 1\%).

All. respondents were male, majority of whom (86\%) belonged to the 36 to, 65 age bracket, which is quite the typical age of Filipino tappers. The longest tapping experience was 42 years while the shortest was 2 years. However, more respondents (46\%) had at least 2 to 10 years tapping experience.

\section{Selection of trees for tapping}

Within the same cultivar there are trees that are inherently good toddy yielders. However, a good nut yielder is not necessarily a good toddy yielder and vice versa.

When respondents were asked of their bases for selecting trees for tapping, JW gave varied answers (Table 2). However, more tappers (7/24) cited that a high toddy-yielding tree has drooping leaves and has pliant leaflets. This observation supports what Nathanael (1 966) earlier held that palms with somewhat shiny and pliable leaflets and whose spadix has a thin inner bract are most likely excellent toddy yielders. Jeganathan(1974), on the other hand, proposed that longer leaves and leaflets are also desirable characters of coconut palms suitable for toddy production.

The said indices are quite interesting, however, Santiago (1983) noted that trees of different spiral tended to vary in toddy yield. If this observation could be verified. and validated, how could it be scientifically explained? Does the said observation suggest that trees of different leaf spiral respond differently to the same environmental factors affecting their physiological functioning? Spiral of the leaves is not known to be hereditary.

\section{The influence of age of tree on toddy yield}

More than half of the respondents (54\%) pointed out that age of tree does not affect toddy yield, but one-third said otherwise, and approximately $12 \%$ responded that they were not aware of it (Table 3). Those who pointed out that age of the tree affects toddy yield specified that trees which are already of age for tapping must:

a) have at least. grown for another two years after the appearance of the first spadix or at least 7 years old.

b) have already reached its peak of nut product. 
Although tappers differed in their responses, this particular observation deserves investigation by researchers. Coconut trees are known to have faster growth rate during their early years of development as evident by vaider gap between leaf-scars. If toddy is a phloem sap, it is possible that in the early years of growth, a bigger quantity of it is utilized for vegetative growth, hence the low toddy yield. Coconut toddy, however, could be a mixture of phloem and xylem sap. Van Die (1 974) proposed that there is a fluid continuity in the xylem vessel system of the nut husk, that of the inflorescence stalk and the vegetative parts of the tree.

\section{The influence of age of spadix on toddy yield}

All, except one respondent, revealed that the age of spadix has a direct influence on toddy yield, such that, it gives too little yield when it is prematurely tapped or if it is way past its prime (Table 4). They also gave indices when a spadix is prime for tapping (Table 5). However, generally their indications are when the youngest inflorescence is about 5-7.5 cm long after it has pierced through the outer spathe, die third youngest is prime (41\%), and button swellings at the spadix's midsection which can be felt by the hand $(25 \%)$.

Although the skill of correctly judging when the spadix has to be tapped or not is a function of experience. Mennon and Pandalai (1958) purported that, as a rule, spadix is considered ready to be operated upon when the one immediately preceding it has just burst open or is about to do so. They also stressed that button development inside the spadix causes a swelling within, which indicates the approximate stage for tapping.

It is a fact that developing organs are, strongly physiological sinks for assimilates. If toddy is assumed to be a phloem sap, naturally, it would move from the leaves to the inflorescence because of the demand of the latter for it. Therefore, does the tappers' observation suggest that the spadix is at its peak of demand for assimilates by the time bulges of the developing buttons can already be detected by hand at midportion? However, this speculation seems weak logically since in appropriately tapped spadix the volume flow of sap increases with time until the peak is reached 2-5 weeks after the first day of collection. The peak will hold on for another 2-3 weeks after which the flow would decline. Santiago (1989) noted that the suitable age of the spadix for tapping varies from tree to tree, i.e. the age of the spadix found suitable for tapping in one tree did not always hold true for other trees.

\section{Preparation and Stimulation of the Spadix for Tapping}

Before the tapping process starts, the appropriate spadix is first 'trained' to a position convenient enough for such operation to take place. Respondents differed slightly in their methods of training die spadix (Table 6). Most of them (63\%) hastened the bending of the spadix by tying its tip, with twine and gradually pulled it downward each day while avoiding breakage at its base, others (29\%) put pressure at the base of the spadix petiole by inserting a stone or a piece of wood between it and the trunk which is carefully adjusted daily, and a few (8\%) slowly removed the stipule supporting the base of the spadix to achieve the same effect. The training period which is commonly simultaneous to the stimulation period ran from 1 to 2 weeks. Among the tapper-respondents and other Visayan tappers, however, stimulation merely involves paring of the spadix in the morning and early evening.

It is quite remarkable that Filipino tappers are overcautious in handling the spadix or the inflorescence, specifically in the training, stimulating and subsequent paring process, in order not to strain it. Whereas, on the West Coast of India, training involved gentle uniform beating all over the surface of the spadix twice a day, in the morning and evening for one week. Then three-fourths of the spadix down is wound with a strong string. After a week's beating, the tip of the spadix is pared, 
and in some places, the naked portion is pounded with the handle of the tapping knife (Menon and Pandalai, 195 8).

\section{Time interval between the first paring and steady toddy flow}

All respondents revealed that they don't make collections during the first or second day of paring because the spadix does not have steady toddy flow yet. Consistent toddy flow was said to have been observed 3-14 days from the first paring (Table 7). This then seems inconceivable since the vascular system is present almost up to the tip of the spadix. Why is some sort of stimulation needed before a longer steady flow of sap would commence? Moreover, why is the flow of toddy hindered or reduced when. the spadix being tapped is premature or overmature?

Menon and Pandalai (1 95 8) contended that the interval from the start of tapping to the actual juice flow depends on the skill of the tapper, the tapping method adopted, the prevailing seasonal conditions and the nature of the tree. This period varies from about ten to twenty-five days.

\section{Care and maintenance of the inflorescence or spadix}

Whenever possible, three-fourths of the respondents said that they protect the inflorescence from early splitting through careful handling and by tying the pared portion with twine (Table 8). Other tappers not included in the interview as observed by the authors used coconut leaflets as the tying material. However, if inevitable, nearly ail tappers (96\%) said that their best remedy is to remove the spathe around and throughout the whole length of the spadix and die exposed spikelets arc tied properly with coconut leaflets or wrapped with banana bracts to prevent larval attack. Most respondents remarked that the presence of larva on the toddy will result to sour and reduced toddy yleld. If this happens, majority (83\%) opened the spadix, cleaned it, removed the larvae and tied or bound it properly, while others $(17 \%)$ covered the inflorescence or spadix with coconut stipules.

\section{Effect on the subsequent toddy yield when the pared portion of the spadix is reached by the level of collected toddy in the collecting receptacle}

About $79 \%$ of the respondents claimed that toddy yield is reduced the next day when the pared portion of the spadix is reached by level of collected toddy in the collecting receptacle (Table 9). They said it takes about 1-4 days before toddy flow becomes normal. This observation is consistent with Santiago's (1989) findings. How will this phenomenon be possibly explained? What physiological event or process is suppressed which consequently reduced sap flow once the spadix comes in contact with the collected toddy? Are the vascular tissues at the tip of the spadix merely impaired by the intoxicating effect of fermentation products resulting from the fermentation process which is most likely in progress in the collected toddy?

\section{Effect of initial Ceriops bark application on toddy yield}

Three-fourths of the tappers claimed that the first application of finely pared Ceriops bark or "tungog " would reduce toddy flow (Table 10) and the adverse effect would last for 1-3 days, after which normal flow returns. What then is in "tungog " which hinders sap flow? What particular sub-system of the spadix is adversely affected by the "tungog" which would lead to the diminution of toddy yield?

\section{Low toddy yield during southwest monsoon months}

More than $60 \%$ of the respondents related that toddy yield is low during the southwest monsoon months (Table 11). Santiago (1989) noted similar observation. What particular atmospheric component during the southwest monsoon season which causes the decline in toddy 
yield? And what specific physiological process is being directly influenced by such atmospheric factor which eventually leads to toddy yield decrement?

The tappers explained that this observation is due to stronger winds that strain the trees, particularly the spadix and to high temperature. In his earlier research, Santiago (1 983) observed a negative relationship between temperature and toddy yield.

Similarly, in a tapping experiment conducted at the Central. Coconut Research Institute in Kasaragod, India, Patel (1983) had observed that during the north-east monsoon, toddy yield was significantly low. Accordingly, this was so because the spadix invariably burst open before the exact stage for tapping was reached.

\section{Impending inclement weather can be detected from the spadix and the collected toddy}

Except two, the rest of the respondents (92\%) disclosed that an incoming weather disturbance which is still 2-8 days away can be detected by the spadix and. the collected toddy (Table 12). This seems to be a very disturbing disclosure. The respondents: said that during the rainy seasons a sudden discoloration or purpling of the spadix and reduced sap flow indicated an impending drought. Likewise, during the dry season a sudden reduction in toddy collection and the presence of whitish solid substances on the collected toddy indicate a forthcoming typhoon or heavy rain. If this observation is to be given credence, what logical speculative explanation would we offer for it? What specific atmospheric component in the immediate surrounding of the coconut tree is altered by the weather disturbance which is still 2-8 days away? What specific metabolic process is altered that would lead to the sudden discoloration of the spadix and toddy yield reduction when drought is forthcoming, or the formation of whitish solid particles and decrement. in sap flow when a heavy rainfall or typhoon is on the way?

\section{Temporary cessation of inflorescence production}

All respondents (100\%) had observed that coconut palms temporarily stop producing inflorescence or spadix. They called it '7ayag" In Cebuano (i.e., the dialect of the people in Cebu and Western and Southern Leyte) or "tangdaw" in Waray (the language of the residents of Northern Leyte and Samar). They explained that the phenomenon is normal among living organisms and is a sort of "rest" period in the plant's productive cycle. However, three respondents (12\%) said it is more prevalent during the months of October and November.

When tappers were asked of their management practice to arrest temporary rest in spadix production and. tap trees the year- round, nearly $80 \%$ said that normal as it is, they need not do anything (Table 13). However, 2 respondents $(8 \%)$ recommended ring weeding arid another three suggested fertilization and proper cultural practices, avoiding continuous tapping arid piercing a hardwood through the coconut think, respectively.

Tappers, however, pointed out that coconut resumes its spadix bearing activity in 1 to 8 months time. 


\section{REFERENCES}

JEGANATHAN, M. 1974. Toddy yield from hybrid coconut palms. Ceylon Coconut Quarterly 25: $139-148$

MENON, K.P.V. arid PANDALAI, K.M. 1958. The Coconut Palm A Monograph Part tl. Indian Central Committee. Ernakulam, South India. 384 pp.

NATHANAEL, W.R.N. 1966. A tapping technique for the coconut palm. Ceylon Coconut Center's Review. 4(4):87-99.

PATEL, J.S. 1983. The Coconut- A Monograph. Government Press, Madras, India.

SANTIAGO, R.M. 1983. Toddy yield of coconut as influenced by fertilization, leaf nutrients, water status, climatic factors arid morphological characters. Ph.D. Dissertation-UP at Los Banos, College, Laguna, Phil. 121 pp.

SANUAGO, R. M. 1989. Coconut yield Mi relation to leaf water status arid some climatic factors. Phil. Journal of Coconut Studies. 14(1): 3237.

VAN DIE, J. 1974. The developing fruits of Cocos Nucifera and Phoenix dactylifera as physiological sinks importing arid assimilating the mobile aqueous phase of the siene tube system. Acta Botany (Neerl.) 23: 521-540

\section{ACKNOWLEDGMENT}

Special thanks to Horticulture 216 (Applied Horticulture Crop Physiology) students of the Department of Horticulture, VisCA, Baybay, Leyte, Philippines who helped conduct the interview. 
Table 1: Respondent's origin, age and tapping experience

\begin{tabular}{|c|c|c|}
\hline Description & No. of respondents & Percent (\%) \\
\hline \multicolumn{3}{|c|}{ A. Origin/Province } \\
\hline Western Leyte & 8 & 33.33 \\
\hline Northern Leyte & 2 & 8.33 \\
\hline Southern Leyte & 2 & 8.33 \\
\hline Eastern Leyte & 5 & 20.83 \\
\hline Cebu & 7 & 29.17 \\
\hline TOTAL & 24 & 100.00 \\
\hline \multicolumn{3}{|l|}{ B. Age (years) } \\
\hline $26-35$ & 1 & 4.17 \\
\hline $36-45$ & 7 & 29.17 \\
\hline $46-55$ & 7 & 29.17 \\
\hline $56-65$ & 7 & 29.17 \\
\hline $66-75$ & 2 & 8.33 \\
\hline TOTAL & 24 & 100.00 \\
\hline \multicolumn{3}{|c|}{ C. Tapping Experience (Years) } \\
\hline $1-10$ & 11 & 45.83 \\
\hline $11-20$ & 7 & 29.17 \\
\hline $21-30$ & 1 & 4.17 \\
\hline $31-40$ & 3 & 12.5 \\
\hline $41-50$ & 2 & 8.33 \\
\hline TOTAL & 24 & 100 \\
\hline
\end{tabular}


Table 2: Indices of a high toddy-producing tree as suggested by experienced tappers

\begin{tabular}{|l|l|c|}
\hline \multicolumn{2}{|c|}{ Indices } & $\begin{array}{c}\text { Frequency (N = } \\
\text { multiple response) }\end{array}$ \\
\hline 1. & Leaves are damaged by beetle/weevil & 1 \\
\hline 2. & Leaves are drooping and leaflets have pliant appearance & 7 \\
\hline 3. & Parts of the stipule are retained at the petiole of older fronds & 2 \\
\hline 4. & Stipule has big fibers but with fine weaves & 3 \\
\hline 5. & Fronds are big and spreading (not upright) & 1 \\
\hline 6. & Frond not easily lacerated & 1 \\
\hline 7. & Spadix is soft and tender; easy to cut & 1 \\
\hline 8. & Fiber-like materials hang at the tip of the frond & 2 \\
\hline 9. & Spadix is long and leaves are dark green & 1 \\
\hline 10. & Tree is left spiralled & 2 \\
\hline 11. & Exudates flow profusely at the base of the trunk when wounded & 1 \\
\hline 12. & Spadix is healthy and robust & 1 \\
\hline 13. & Tree bears many fruits & 1 \\
\hline 14. & Tree has deep frond scar & 2 \\
\hline
\end{tabular}

Table 3: Respondents' observation on the influence of age of coconut tree to toddy yield

\begin{tabular}{|l|r|c|}
\hline \multicolumn{1}{|c|}{ Observation } & No. of & Percent Respondents \\
\hline Age does not affect toddy yield & 13 & 54.17 \\
Age affects toddy yield & 8 & 33.33 \\
Not aware of any effect & 3 & 12.50 \\
TOTAL & $\mathbf{2 4}$ & $\mathbf{1 0 0 . 0 0}$ \\
\hline
\end{tabular}

Table 4: Respondents' observation on the influence of age of spadix to toddy yield

\begin{tabular}{|l|c|c|}
\hline \multicolumn{1}{|c|}{ Observation } & No. of Respondents & Percent (\%) \\
\hline Age affects toddy yield & 23 & 95.83 \\
No answer & 1 & 4.17 \\
TOTAL & $\mathbf{2 4}$ & $\mathbf{1 0 0 . 0 0}$ \\
\hline
\end{tabular}


Table 5: Respondents' indices when a spadix is prime for tapping

\begin{tabular}{|l|c|c|}
\hline \multicolumn{1}{|c|}{ Responses } & $\begin{array}{c}\text { No. of } \\
\text { Respondents }\end{array}$ & Percent \\
\hline When the youngest unopened spadix is already 5 & 10 & 41.66 \\
$7.5 \mathrm{~cm}$ long, the third youngest one is prime & 6 & 25.00 \\
Button swellings can be felt by hand at the spadix's & 1 & 4.17 \\
midsection & 1 & 4.17 \\
When spadix is about 60 cm long and hard to, feel & 3 & 12.50 \\
When spadix is 3-month old & 3 & 12.50 \\
When spadix looks rounded and hard to the feel & $\mathbf{2 4}$ & $\mathbf{1 0 0 . 0 0}$ \\
No definite answer & & \\
TOTAL &
\end{tabular}

Table 6: Respondents' techniques in training inflorescence

\begin{tabular}{|l|c|c|}
\hline \multicolumn{1}{|c|}{ Subject } & $\begin{array}{c}\text { No. of } \\
\text { respondents }\end{array}$ & Percent (\%) \\
\hline A. " Training" technique & 15 & 62.50 \\
\hline $\begin{array}{l}\text { By tying the tip of the spadix with twine and slowly } \\
\text { pulling it down ward each day while avoiding breakage at } \\
\text { its base }\end{array}$ & 7 & 29.17 \\
\hline $\begin{array}{l}\text { By inserting a stone or a piece of wood between the base } \\
\text { of the spadix, petiole and trunk }\end{array}$ & 2 & 8.33 \\
\hline By gradual removal of the stipule or 'guinit' & $\mathbf{2 4}$ & $\mathbf{1 0 0 . 0 0}$ \\
\hline TOTAL & 23 & 95.83 \\
\hline B. 'Training' period (days) & 1 & 4.17 \\
\hline 3-7 & $\mathbf{2 4}$ & $\mathbf{1 0 0 . 0 0}$ \\
\hline $8-14$ & & \\
\hline TOTAL & & \\
\hline
\end{tabular}

Table 7. Interval from first paring to steady flow as observed by respondents

\begin{tabular}{lcc}
\hline Interval (days) & No. of respondents & Percent $(\%)$ \\
\hline $3-7$ & 21 & 87.50 \\
$8-14$ & 3 & 12.50 \\
- \hdashline-------- & 100.00
\end{tabular}


Table 8: Inflorescence/spadix care and maintenance practices adopted by respondents

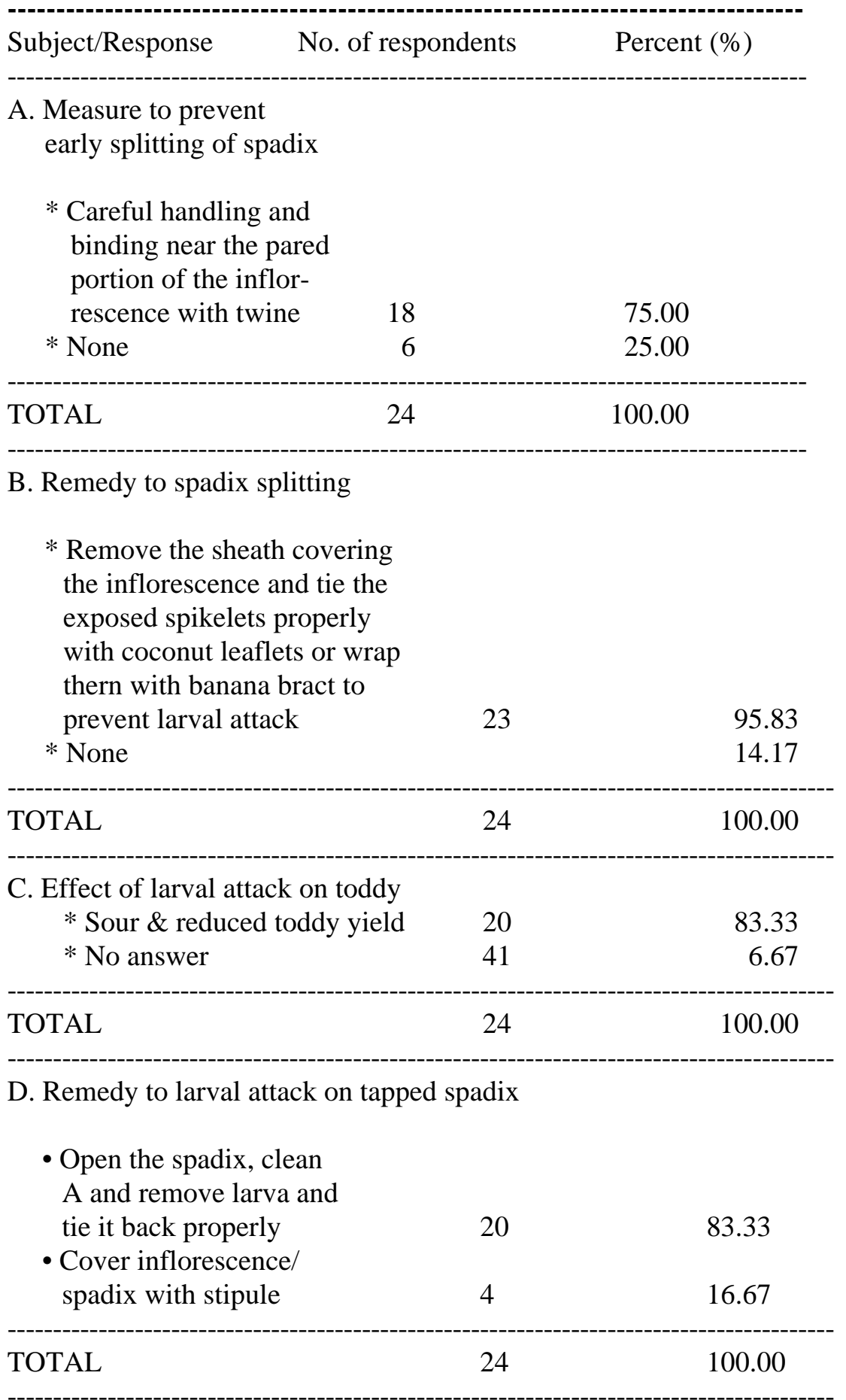


Table 9: Effect on toddy yield when the pared portion of the spadix is reached by the level of toddy in the collecting receptacle as observed by respondents

$\begin{array}{lcc} & \text { No. of respondents } & \text { Percent } \\ \text { Effect } & 19 & 79.16 \\ \begin{array}{l}\text { Yield is reduced the } \\ \text { next day }\end{array} & 16.67 \\ \text { No effect on toddy yield } & 4 \\ \begin{array}{l}\text { Had not known/ } \\ \text { observed if there's } \\ \text { any effect }\end{array} & 1 & 4.17 \\ - & & \\ \text { TOTAL } & 24 & 100.00\end{array}$

Table 10: Effect of initial Ceriops bark application on toddy as observed by respondents

\begin{tabular}{lcc}
- & No. of respondents & Percent (\%) \\
\hline Reduced toddy yield & 18 & 75.00 \\
No effect & 3 & 16.67 \\
No answer & 2 & 8.33 \\
------------------------------------------ \\
TOTAL & 24 & 100.00
\end{tabular}

Table 1 1: Toddy yield during southwest monsoon season as observed by respondents

\begin{tabular}{|c|c|c|}
\hline Observation & No. of respondents & Percent $(\%)$ \\
\hline Reduced yield (RY) & 15 & 62.50 \\
\hline Increased yield (IY) & 6 & 25.00 \\
\hline No answer & 2 & 8.33 \\
\hline No difference in yield & 1 & 4.17 \\
\hline TOTAL & 24 & 100.00 \\
\hline \multicolumn{3}{|l|}{ Explanation for RY } \\
\hline $\begin{array}{l}\text { Spadix is strained by } \\
\text { strong winds }\end{array}$ & 13 & 86.66 \\
\hline High temperature & 1 & 6.67 \\
\hline No explanation & 1 & 6.67 \\
\hline Total 15 & & 100.00 \\
\hline $\begin{array}{l}\text { Explanation for IY } \\
\text { Wind comes only } \\
\text { from one direction } \\
\text { hence spadix is not } \\
\text { strained }\end{array}$ & 6 & 100.00 \\
\hline
\end{tabular}


Table 12: Respondents' observation regarding the relation between incoming weather disturbance (IWD) and spadix and toddy appearance

\begin{tabular}{|c|c|c|}
\hline Observation & No. of respondents & Percent \\
\hline $\begin{array}{l}\text { IWD is detected on the } \\
\text { toddy thru the presence } \\
\text { of whitish particles and } \\
\text { spadix discoloration }\end{array}$ & 22 & 91.67 \\
\hline $\begin{array}{l}\text { IWD can't be detected on } \\
\text { the toddy }\end{array}$ & n & 8.33 \\
\hline TOTAL & 24 & 100.00 \\
\hline \multicolumn{3}{|c|}{$\begin{array}{l}\text { No. of days when IWD is detected } \\
\text { on the toddy and spadix }\end{array}$} \\
\hline $\begin{array}{l}2 \text { - } 8 \text { days before the } \\
\text { actual weather } \\
\text { disturbance }\end{array}$ & 19 & 86.36 \\
\hline can't determine & 2 & 9.09 \\
\hline no answer & 1 & 4.54 \\
\hline TOTAL & 22 & 99.99 \\
\hline
\end{tabular}

Table 13: Respondents' cultural practices to prevent temporary cessation of inflorescence or spadix production in coconut

\begin{tabular}{|c|c|c|}
\hline Cultural practices & No. of respondents & Percent \\
\hline None & 19 & 79.16 \\
\hline Ringweeding & 2 & 8.33 \\
\hline $\begin{array}{l}\text { Fertilization \& proper } \\
\text { care \& management }\end{array}$ & 1 & 4.17 \\
\hline $\begin{array}{l}\text { Piercing a piece of hardu } \\
\text { thru the coconut trunk }\end{array}$ & wood & 4.17 \\
\hline Avoid continuous tappin & 1 & 4.17 \\
\hline Total & 24 & 100.00 \\
\hline
\end{tabular}

